Etnográfica

Revista do Centro em Rede de Investigação em

Antropologia

vol. $13(1) \mid 2009$

Vol. $13(1)$

Cláudia Castelo, Passagens para África: o Povoamento de Angola e Moçambique com Naturais da Metrópole

Jorge Varanda

CpenEdition

Journals

Edição electrónica

URL: https://journals.openedition.org/etnografica/1281

DOI: 10.4000/etnografica.1281

ISSN: 2182-2891

Editora

Centro em Rede de Investigação em Antropologia

Edição impressa

Data de publição: 2 maio 2009

Paginação: 227-228

ISSN: 0873-6561

Refêrencia eletrónica

Jorge Varanda, «Cláudia Castelo, Passagens para África: o Povoamento de Angola e Moçambique com Naturais da Metrópole», Etnográfica [Online], vol. 13 (1) | 2009, posto online no dia 16 maio 2012, consultado o 10 fevereiro 2022. URL: http://journals.openedition.org/etnografica/1281 ; DOI: https:// doi.org/10.4000/etnografica.1281

Etnográfica is licensed under a Creative Commons Attribution-NonCommercial 4.0 International License. 


\section{Cláudia Castelo \\ PASSAGENS PARA ÁFRICA: \\ O POVOAMENTO DE ANGOLA \\ E MOÇAMBIQUE COM NATURAIS DA METRÓPOLE}

Porto, Edições Afrontamento, 2007, 405 páginas.

O império exige colonizadores, pessoas, quer seja para conquistar, impor a ordem, evangelizar, administrar o território e populações locais, promover comércio ou indústria. Apesar da centralidade dos diversos actores colonizadores - militares, administradores, profissionais liberais, comerciantes, agricultores - a historiografia portuguesa não apresentava até à tese de doutoramento de Cláudia Castelo estudos aprofundados e críticos sobre a colonização branca das colónias africanas portuguesas. O livro Passagens para África: O Povoamento de Angola e Moçambique com Naturais da Metrópole, corolário da tese, tem como objecto a migração de naturais da metrópole para as colónias de Angola e Moçambique entre 1920 e 1970.

Após ter trabalhado sobre o impacte e a incorporação do luso-tropicalismo de Gilberto Freyre na ideologia colonial portuguesa ("O Modo Português de Estar no Mundo": O Luso-tropicalismo e a Ideologia Colonial Portuguesa (1933-1961), Porto, Edições Afrontamento, 1998), Cláudia Castelo enfrentou uma montanha de fontes primárias e publicações da época com ferramentas metodológicas da história, demografia, sociologia, antropologia e psicologia social para estudar os discursos coloniais de povoamento, os actores históricos e as representações destes sobre os territórios e populações coloniais.

As diferentes perspectivas sobre o processodepovoamentoreflectem-senasegmentação do livro em três partes. $\mathrm{Na}$ primeira são analisados os modelos de povoamento branco, as políticas oficiais e concepções ideológicas subjacentes, e posteriormente a autora caracteriza demográfica e sociologicamente as populações que seguiram para estes territórios ultramarinos, revelando na terceira parte as representações dos colonos sobre eles próprios, a terra e os habitantes autóctones, pontuadas com episódios das condições de vida no terreno e do relacionamento com as populações locais. As duas correntes - colonização intensiva com populações da metrópole dirigida pelo Estado; colonização de capitais e quadros sem intervenção estatal - definiam o tipo de ocupação, papel do Estado, perfil dos colonos e relação destes com a população local. Ou seja, apresentavam abordagens diferentes ao projecto colonial, mas com a sobrevivência da Nação como base comum.

A persistência de discursos e políticas de emigração do último quartel do século XIX ao final do projecto colonial inferia a existência de problemas na concretização destas ideias. Angola e Moçambique, apesar de serem destinos preferenciais na emigração para as colónias, não eram, no entanto, o destino principal da emigração portuguesa. Numa caracterização macro, a autora trabalha uma miríade de dados para apresentar os perfis dos emigrantes, revelando sexo, idade, estado civil, escolaridade, aptidão profissional, distrito de origem na metrópole e de fixação na colónia, condições de viagem, e estabelece quais os momentos históricos de maior ou menor fluxo migratório. A autora revela ainda que, no que toca à colonização dirigida, o Estado promoveu o oposto de representações e políticas de povoamento, demonstrando que a colonização livre, isto é, sem intervenção do governo, foi o grande motor da emigração para as colónias.

$\mathrm{Na}$ terceira parte Cláudia Castelo ilustra as representações dos colonos sobre eles mesmos e o meio circundante, a metrópole, e ainda a centralidade destas representações para a construção da sua identidade. Patenteia a distância existente entre os colonos e a metrópole política. Mostra as condições 
de vida de colonos e africanos em ambas as colónias ao longo do tempo, contrapondo às representações coloniais casos específicos de terreno que revelam a complexidade da situação colonial e a fragmentação da experiência colonial.

Metodologicamente, ao integrar instrumentos de diversos campos do conhecimento, história, demografia, sociologia e antropologia, a autora fornece uma lufada de ar fresco aos estudos coloniais portugueses. A base sólida de fontes primárias pesquisadas nos meandros dos arquivos portugueses, angolanos e moçambicanos, o olhar crítico sobre os censos e a literatura da época, o entrelaçar de dados quantitativos e qualitativos, as análises de representações e discursos e dos diferentes níveis activos no objecto tornam o argumento deste trabalho mais coerente e persuasivo. O corolário desta interdisciplinaridade é um livro que avança uma imagem mais complexa sobre o povoamento das colónias de Angola e Moçambique no Terceiro Império Português.

A autora poderia ter dado outros passos em frente, por exemplo prosseguido a linha de investigação da história oral, seguindo o exemplo de estudos originários da academia norte-americana - Nancy Hunt, $A$ Colonial Lexicon: Of Birth Ritual, Medicalization and Mobility in the Congo (Durham, NC, Duke University Press, 1999); Luise White, Speaking with Vampires: Rumor and History in Colonial Africa (Berkeley, University of California Press, 2000); Jeremy Ball, "The Colossal Lie": The Sociedade Agricola do Cassequel and Portuguese Colonial Labor Policy in Angola, 1899-1977 (tese de doutoramento, Los Angeles, University of California, 2003). Os testemunhos orais, ao invés dos arquivos, desaparecem diariamente, e apesar de divagações e visões de um passado dourado, outorgam informações-chave ausentes de censos, relatórios coloniais, bibliografia de época ou literatura de memórias coloniais. Este trabalho, em particular a parte III, ganharia maior força analítica ao incluir elementos de história oral. Tal iluminaria de forma clara aspectos como as redes presentes no processo de emigração, as motivações para emigrar e a escolha do local de chegada, o papel da ideologia política do colono na ida para as colónias ou as representações africanas dos colonos, e outorgaria maior detalhe às situações de caracterização micro, como a vivência do dia-a-dia dos colonos e as suas dificuldades, as hierarquias e tensões entre colonizadores, o quotidiano e a capacidade de agenciamento dos africanos. O resultado seria um reforço da história crítica vista de baixo, enfatizando-se o hiato entre a experiência no terreno colonial e os discursos e representações coloniais, produzindo-se uma imagem mais complexa e sofisticada do projecto e da realidade coloniais.

Dito isto, este trabalho revela o processo de maturação que os estudos coloniais em Portugal tiveram nos últimos anos. Apresenta um olhar crítico e contextualizado dos discursos e políticas de povoamento, ilumina o hiato entre estes discursos e a prática dos planos de povoamento metropolitanos, integra a metrópole e as colónias num mesmo patamar de análise, mostra a força analítica ao descartar conceptualizações maniqueístas e homogeneizantes do contexto colonial e consegue uma harmonia salutar entre a extensão e a profundidade do estudo.

Quem trabalha sobre o Império defronta um dilema quando procura encontrar o ponto de equilíbrio entre os dois discursos dominantes, as representações hegemónicas do período colonial e as caracterizações anticoloniais, ambos com um lastro ainda aceso no presente. Cláudia Castelo atinge este equilíbrio, contribuindo de forma importante para uma imagem mais complexa do projecto colonial português.

\section{Jorge Varanda}

CRIA, CMDT-LA 